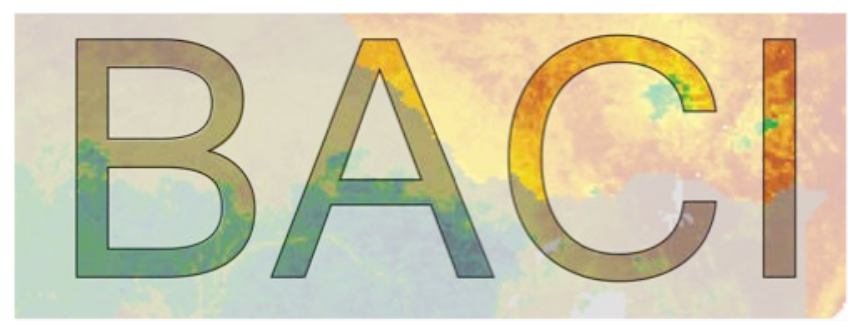

\title{
Biomass turnover time in terrestrial ecosystems halved by land use
}

\section{Postprint version}

\author{
Erb, K.-H., Fetzel, T., Plutzar, C., Kastner, T., Lauk, C., Mayer, A., \\ Niedertscheider, M., Körner, C., Haberl, H.
}

Published in: $\quad$ Nature geoscience

Reference: Erb, K.-H., Fetzel, T., Plutzar, C., Kastner, T., Lauk, C., Mayer, A., Niedertscheider, M., Körner, C., Haberl, H. (2016). Biomass turnover time in terrestrial ecosystems halved by land use. Nature geoscience, 9, 674-678. doi:10.1038/ngeo2782

Web link: http://www.nature.com/ngeo/journal/v9/n9/full/ngeo2782.html 


\title{
Biomass turnover time in terrestrial ecosystems halved by land use
}

\author{
Karl-Heinz Erb ${ }^{1 \star}$, Tamara Fetzel ${ }^{1}$, Christoph Plutzar ${ }^{1,2}$, Thomas Kastner ${ }^{1}$, Christian Lauk ${ }^{1}$, \\ Andreas Mayer ${ }^{1}$, Maria Niedertscheider ${ }^{1}$, Christian Körner ${ }^{3}$ and Helmut Haberl ${ }^{1}$
}

The terrestrial carbon cycle is not well quantified ${ }^{1}$. Biomass turnover time is a crucial parameter in the global carbon cycle $^{2-4}$, and contributes to the feedback between the terrestrial carbon cycle and climate ${ }^{2-7}$. Biomass turnover time varies substantially in time and space, but its determinants are not well known ${ }^{8,9}$, making predictions of future global carbon cycle dynamics uncertain ${ }^{5,10-13}$. Land use-the sum of activities that aim at enhancing terrestrial ecosystem services $^{14}$-alters plant growth ${ }^{15}$ and reduces biomass stocks ${ }^{16}$, and is hence expected to affect biomass turnover. Here we explore land-use-induced alterations of biomass turnover at the global scale by comparing the biomass turnover of the actual vegetation with that of a hypothetical vegetation state with no land use under current climate conditions. We find that, in the global average, biomass turnover is 1.9 times faster with land use. This acceleration affects all biomes roughly equally, but with large differences between land-use types. Land conversion, for example from forests to agricultural fields, is responsible for $59 \%$ of the acceleration; the use of forests and natural grazing land accounts for $26 \%$ and $15 \%$ respectively. Reductions in biomass stocks are partly compensated by reductions in net primary productivity. We conclude that land use significantly and systematically affects the fundamental trade-off between carbon turnover and carbon stocks.

Biomass turnover time $\left(\tau_{\mathrm{b}}\right)$ is a critical parameter of the global carbon cycle and a key vegetation property ${ }^{1,3,5} \cdot \tau_{\mathrm{b}}$ is a decisive parameter for the elemental composition (stoichiometry) of ecosystems, critically influencing the accumulation and availability of chemical elements in ecosystems, rendering $\tau_{\mathrm{b}}$ a key factor for plant growth dynamics ${ }^{17}$ and a crucial determinant of fluxes between terrestrial vegetation and the atmosphere $e^{3-7}$. Because $\tau_{\mathrm{b}}$ is an ecosystem property that emerges from the interplay between climate, soil, vegetation type, the chemical composition of the atmosphere, precipitation, and land use, it is highly variable across space and time $e^{8,9}$. However, patterns and determinants of the variability of $\tau_{\mathrm{b}}$ are poorly understood $\mathrm{d}^{5,9,18}$. In particular, the inability of land-cover or plant functional type classifications, which form the basis of many carbon cycle model ${ }^{8,10}$, to comprehensively represent the variability of $\tau_{\mathrm{b}}$ induces massive uncertainties in predictions of future global carbon cycle dynamics ${ }^{1,5,8,10-13,19}$. Thus, improving the understanding of covariates for $\tau_{\mathrm{b}}$ is central to understanding the biosphere's responses to a changing climate.

Land use is a pervasive driver of global change ${ }^{14,20,21}$ that results in land conversions, for example, the replacement of pristine ecosystems with agroecosystems, as well as in changes of stocks and flows of carbon within the same land-cover type (denoted 'land modifications' ${ }^{22}$. By replacing ecosystems dominated by perennial, often woody lifeforms with agroecosystems dominated by annual, herbaceous lifeforms, land use obviously accelerates biomass turnover $\left(\tau_{\mathrm{b}}\right)$. Moreover, land use affects both productivity ${ }^{15,23}$ and carbon storage ${ }^{16,24}$ also within land-cover types. While reductions in biomass $\mathrm{C}$ stocks (SC) tend to accelerate $\tau_{\mathrm{b}}$, reductions in terrestrial productivity (which happen frequently ${ }^{15,21,23}$ ) would reduce $\tau_{\mathrm{b}}$. A comprehensive, global, spatially explicit quantification of the interplay of these effects for $\tau_{\mathrm{b}}$ is missing at present, despite its obvious importance.

Complementary to previous attempts to understand determinants of patterns of $\mathrm{C}$ turnover time ${ }^{1,8}$, which did not explicitly analyse land use as a covariate, we here aim to explore the role of land use as a determinant of rates and patterns of $\tau_{b}$. By adopting an approach that has proved useful in quantifying land-use effects on ecosystem properties such as net primary production (NPP) ${ }^{15,20,21}$, we here compare $\tau_{\mathrm{b}}$ of the potential and the actual vegetation. The potential vegetation refers to a hypothetical condition that would prevail in the assumed absence of land use but under current climate ${ }^{15}$. We define the acceleration of $\tau_{\mathrm{b}}$ as turnover of the potential natural vegetation divided by actual turnover:

$$
\begin{gathered}
\tau_{\mathrm{b}} \text { acceleration }=\tau_{\text {bpot }} / \tau_{\text {bact }} \\
=\frac{\mathrm{SC}_{\mathrm{pot}}}{\mathrm{NPP}_{\mathrm{pot}}} \frac{\mathrm{SC}_{\mathrm{act}}}{\mathrm{NPP}_{\mathrm{act}}}
\end{gathered}
$$

This approach allows us to quantify the scale of land-use-induced impacts on $\tau_{\mathrm{b}}$ in the absence of data sets on past land-use dynamics. While it would be intriguing to model the land-useinduced impacts on ecosystem turnover time (that is, including soil compartments), the lack of adequate and robust data sets ${ }^{25}$ restricts this study to $\tau_{\mathrm{b}}$. To avoid oversimplifications or steadystate assumptions about, for example, plant functional types ${ }^{1}$, we do not rely on a mechanistic model for our assessment, but base our approach on the consistent integration of available data sets. Four independent data sets were established: the living biomass stock of carbon of the potential $\left(\mathrm{SC}_{\mathrm{pot}}\right)$ and actual vegetation $\left(\mathrm{SC}_{\text {act }}\right)$, as well as NPP of the potential $\left(\mathrm{NPP}_{\mathrm{pot}}\right)$ and of the actual vegetation $\left(\mathrm{NPP}_{\mathrm{act}}\right)$. 'Actual vegetation' refers to the year 2000. Data limitations restrict the study to a temporal resolution of one year. To isolate and quantify the effects of individual land uses we use a comprehensive land-use data $\operatorname{set}^{14}$ that distinguishes the six landuse types: infrastructure; cropland; forestry; artificial grasslands; natural grasslands without trees; savannah, other wooded land, shrubs and grassland-tree mosaics, as well as untouched areas (see Supplementary Information). Spatially explicit $\mathrm{NPP}_{\text {pot }}$ was derived

\footnotetext{
${ }^{1}$ Institute of Social Ecology Vienna, Alpen-Adria Universitaet Klagenfurt - Vienna - Graz, Schottenfeldgasse 29, 1070 Vienna, Austria. ${ }^{2}$ Division of Conservation Biology, Vegetation Ecology and Landscape Ecology, University of Vienna, Rennweg 14, 1030 Vienna, Austria. ${ }^{3}$ Institute of Botany, University of Basel, Schönbeinstrasse 6, 4056 Basel, Switzerland. *e-mail: karlheinz.erb@aau.at
} 

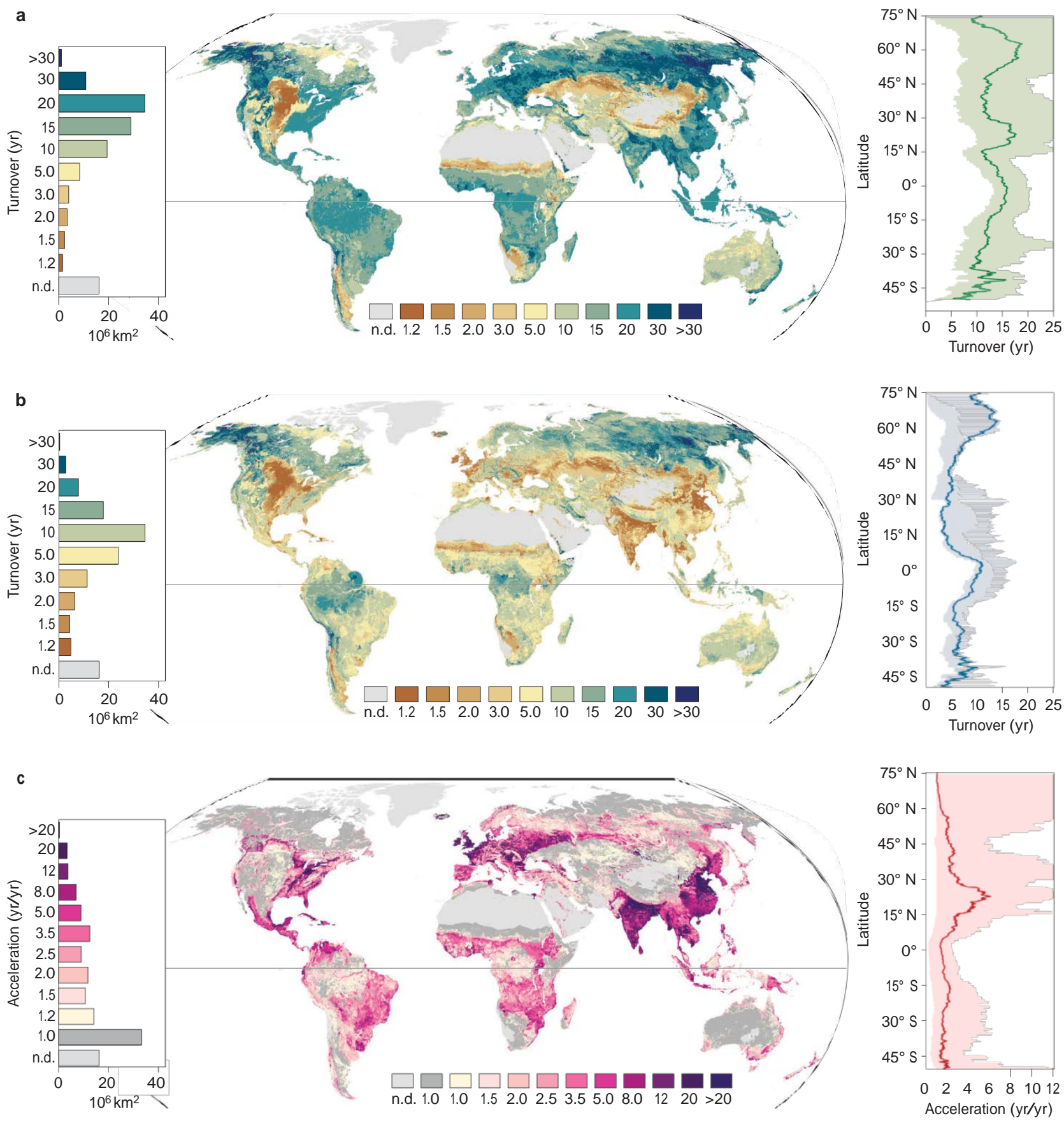

Figure 1 | Global human acceleration of biomass turnover, spatial pattern, histogram and latitudinal profiles. a-c, Potential biomass turnover ( $\tau$ bpot ) in years (a), actual biomass turnover in years ( $\tau_{\text {bact }}$ ) (b), and acceleration of biomass turnover (c), calculated as the ratio of $\tau_{b p o t}$ to $\tau_{b}$ bact. The shaded area in the latitudinal profiles (right-hand plots) relates to the entire range of calculations for $\tau_{\mathrm{b} a c t}, \tau_{\mathrm{bpot}}$, and for $\tau_{\mathrm{b}}$ acceleration resulting from 216 combinations of independent data sets for SC and NPP (Supplementary Information). Histograms (left-hand plots) show the area under $\tau_{b}$ classes for $\mathbf{a}$ and $\mathbf{b}$ and acceleration classes for $\mathbf{c}$. n.d., not defined.

by calculating the cell-based arithmetic mean of three different $\mathrm{NPP}_{\text {pot }}$ maps (Supplementary Information). NPP act was derived by applying factors for land-use-induced productivity changes ${ }^{15}$ to $\mathrm{NPP}_{\text {pot }}$. $\mathrm{SC}_{\text {pot }}$ was calculated by combining three biome maps with typical carbon stock values for undisturbed ecosystems. $\mathrm{SC}_{\mathrm{act}}$ of managed and untouched forests was downscaled from ref. 26 using tree-height information (Supplementary Information). $\tau_{\text {bact }}$ of cropland and artificial grasslands was assumed to be $1 \mathrm{yr}$ (see Supplementary Information). An uncertainty analysis, based on additional data sets for $\mathrm{SC}_{\text {pot }}, \mathrm{SC}_{\mathrm{act}}, \mathrm{NPP}_{\text {pot }}$ and $\mathrm{NPP}_{\text {act }}$, was undertaken (Supplementary Information).
Land use has accelerated $\tau_{\mathrm{b}}$ globally by a factor 1.9 (Fig. 1). In the potential vegetation, mean $\tau_{\mathrm{b}}$ would amount to $13.7 \mathrm{yr}$ (Fig. 1a), compared to $7.1 \mathrm{yr}$ in the actual vegetation (Fig. 1b). The uncertainty analysis reveals that our results are well within the range of estimates (see Fig. 1c and Supplementary Information, Supplementary Tables 14-17). These $\tau_{\mathrm{b}}$ values refer to the entire terrestrial living biomass, averaged across all world regions, ecosystems, land-use types and biomass compartments (for example, woody biomass, leaves or roots). The spatial variation of the land-use-induced $\tau_{\mathrm{b}}$ acceleration is massive. $39 \%$ of the land surface experiences no change, $19 \%$ has a $\tau_{\mathrm{b}}$ acceleration below 1.5 , while $21 \%$ experiences 
a moderate (between 1.5 and 3), and $21 \%$ a massive acceleration of $\tau_{\mathrm{b}}$ of $>3$. The highest turnover acceleration values are found in the agricultural belt in India, China, Latin America, Eastern US and Europe, with the lowest in zones of remote tropical and boreal forests, but also in steppes. At a sub-annual level, one can suspect a stronger $\tau_{\mathrm{b}}$ acceleration because cropland agriculture is commonly associated with a shortening of the growing season.

The acceleration of $\tau_{\mathrm{b}}$ is almost uniformly at or close to 2 across latitudes (Fig. 1c). The lack of variability across latitudinal bands indicates that land use is an important factor in almost all regions, and not limited to certain climatic zones. The remarkable exception to this uniformity is the high acceleration of $\tau_{\mathrm{b}}$ in the subtropical belt between 10 and $30^{\circ} \mathrm{N}$. This region is dominated by agricultural belts with intensive land use on the Indian subcontinent and East Asia, and otherwise consists mainly of deserts. Potential as well as actual $\tau_{\mathrm{b}}$ show a complex latitudinal profile, influenced by the distribution of lifeforms such as trees and grasslands. A particularly large level of disagreement of input data occurs at northern high latitudes (Fig. 1c and Supplementary Table 16). The pattern found for actual $\tau_{\mathrm{b}}$ differs markedly from the latitudinal profile of total ecosystem carbon turnover (including soil C), which shows a strong $\mathrm{U}$-shape ${ }^{8}$, suggesting that latitude effects are stronger for soil turnover than for $\tau_{\mathrm{b}}{ }^{19}$.

Our assessment confirms the large variability of $\tau_{\mathrm{b}}$ within and between terrestrial biomes ${ }^{9,18}$ (Fig. 2). Land use strongly and systematically accelerates $\tau_{\mathrm{b}}$ across all biomes. Because land conversion is a well-known driver of soil carbon loss ${ }^{16}$, and also management of forests for production might reduce $\mathrm{SOC}^{25}$, one might suspect that land use might also accelerate total carbon turnover (that is, including the soil compartment). For a robust quantification, however, better data are needed.

$\tau_{\mathrm{b}}$ acceleration affects all biomes, with the land-use impact of biomass $\mathrm{C}$ stocks prevailing over the impact on $\mathrm{C}$ fluxes (that is, NPP; Fig. 2a). In particular, the (sub)tropical biome is strongly affected by reductions in carbon stocks. Land-use effects are particularly strong in the temperate forest biome, but also in the tropical savannah and grassland biome. In these biomes, biomass stocks and productivity per unit area are similar, but $\tau_{\text {bpot }}$ is much slower in the temperate forest biome (17.1 yr versus $11.6 \mathrm{yr})$. The conversion of pristine ecosystems to agroecosystems and other land uses accelerate $\tau_{\mathrm{b}}$ in the temperate biome to a level of $6.3 \mathrm{yr}$, slightly slower than the $\tau_{\text {bact }}$ of the savannah biome ( $5.5 \mathrm{yr}$ ).

Figure $2 \mathrm{~b}$ and Supplementary Table 12 show the turnover acceleration by land-use type. The harvest intensity of each landuse class ${ }^{20}$ (green diamonds) correlates strongly and negatively with actual $\tau_{\mathrm{b}}$. Changes resulting from agricultural land conversion (to cropland or grassland) are massive compared to the effects due to forestry or the use of natural grazing lands. $\tau_{\mathrm{b}}$ in used forests is accelerated by a factor 1.6 (1.6 in tropical, 1.5 in temperate and 1.3 in boreal forests). The use of savannahs or other wooded lands results in a $\tau_{\mathrm{b}}$ acceleration by 2.0 , while natural (tree-less) grasslands experience only a minor acceleration (1.0). Yet, due to the large areal extent of savannahs or other wooded lands, the contribution to the overall $\tau$ acceleration is substantial.

The $\tau_{\mathrm{b}}$ acceleration ranges from 1.8 to 4.0 for world regions (Table 1). On used land (globally 98.2 million $\mathrm{km}^{2}$ ), the reduction of carbon stocks alone would result in a $\tau_{\mathrm{b}}$ acceleration by 2.4 . However, the prevailing NPP-reduction effect of land use, induced by, for example, a massive shortening of the growing season which can offset an increased productivity per cropping period, results in a decelerating effect of $-10 \%$. Additionally, the weight of individual land-use types in terms of NPP shifts with land use, which results in an additional deceleration of $-6 \%$, so that the overall acceleration is 2.1 on used land (Table 1). Such partly compensating effects are particularly pronounced in Northern Africa and Western Asia as well as in Southern Asia, where the contribution of SC
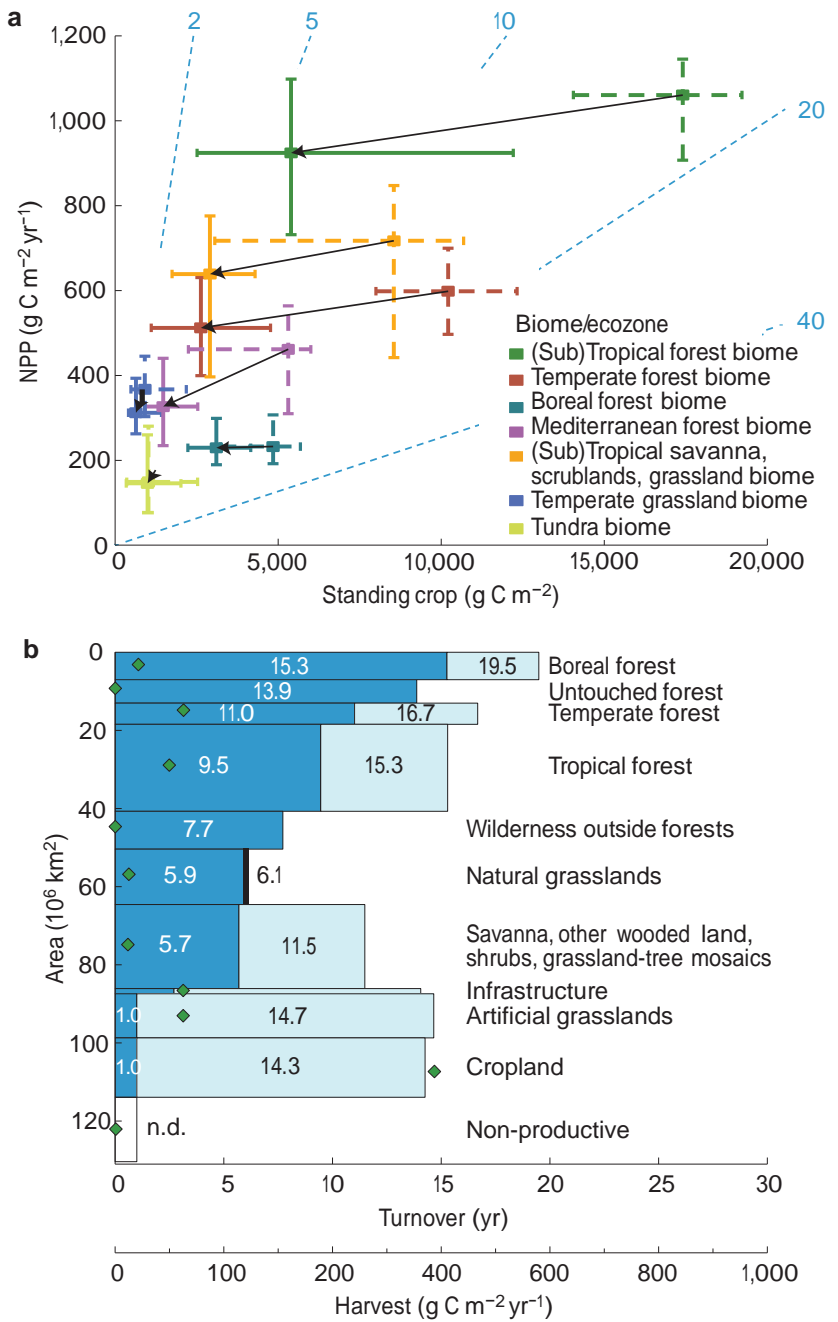

Figure 2 | Land-use-induced acceleration of biomass turnover.

a, Acceleration in the world's biomes. Vectors in a show the change induced by land use. Horizontal and vertical whiskers indicate the range of the inner 50th percentile of all 5 arcmin grid cells for NPP ( $y$ axis) and standing crop ( $x$ axis), crossing at the respective medians within a biome ${ }^{31}$. Dashed crosses refer to potential vegetation, solid crosses to actual vegetation. Blue dashed lines represent isolines with identical $\tau_{\mathrm{b}}$ times but varying NPP-carbon stock combinations; the blue numbers refer to the $\tau_{\mathrm{b}}$ times (yr) of the respective lines; black arrows show the direction of combined changes in C stocks and NPP. b, Acceleration on individual land-use types. The $y$ axis relates to the global land surface extent of each land-use unit (total ice-free surface is $130.4 \times 10^{6} \mathrm{~km}^{2}$ ) sorted along declining $\tau_{\text {bact }}$. Dark blue shaded areas represent actual vegetation and dark and light blue shaded areas combined represent potential vegetation. Numbers indicate $\tau_{\mathrm{b}}$ times (yr) and n.d. represents areas where $\tau_{\mathrm{b}}$ is not defined (non-productive land). Green diamonds indicate harvest intensity per land-use type in 2000 (ref. 20) and refer to the lower $x$ axis. Underlying data are given in Supplementary Tables 11 and 12.

reductions is highest, but relatively strong compensation by NPP reductions occurs.

The contribution of individual land-use types to overall $\tau_{\mathrm{b}}$ acceleration is regionally highly variable (Table 1). In overall terms, cropland contributes $31 \%$ to $\tau_{\mathrm{b}}$ acceleration. Artificial grasslands (for example, pastures on potential forest sites) contribute $25 \%$. However, land modifications also play a significant role, with a mean global contribution of $26 \%$ from forestry, and $15 \%$ from the use of natural grasslands, including savannahs and scrubland. 
Table 1| Acceleration of biomass turnover, contribution of individual major land uses and components, break-down to world regions.

\begin{tabular}{|c|c|c|c|c|c|c|c|c|c|c|c|c|}
\hline & \multirow[b]{3}{*}{ Area } & \multirow[b]{3}{*}{$\begin{array}{l}\boldsymbol{T}_{\mathrm{bpot}} \\
(\mathrm{yr})\end{array}$} & \multirow[b]{3}{*}{$\begin{array}{r}\boldsymbol{T}_{\text {bact }} \\
(\mathrm{yr}) \\
\end{array}$} & \multirow[b]{3}{*}{$\begin{array}{l}\boldsymbol{T}_{\text {baccel }} \\
\text { (factor) } \\
\end{array}$} & \multicolumn{8}{|c|}{ Contribution to acceleration } \\
\hline & & & & & \multicolumn{5}{|c|}{ Land-use types } & \multicolumn{3}{|c|}{ Components } \\
\hline & & & & & $\begin{array}{l}\text { Infrastructure } \\
\begin{array}{l}\text { (\%) } \\
\end{array}\end{array}$ & $\begin{array}{l}\text { Cropland } \\
(\%)\end{array}$ & $\begin{array}{c}\text { Forestry } \\
(\%) \\
\end{array}$ & $\begin{array}{l}\text { Art. } \\
\text { grassl. } \\
(\%) \\
\end{array}$ & $\begin{array}{c}\text { Natural } \\
\text { grassl. } \\
(\%)\end{array}$ & $\begin{array}{l}\text { IUNPP/NPP } \\
(\%) \\
\end{array}$ & $\begin{array}{l}\text { ANPP } \\
(\%) \\
\end{array}$ & $\begin{array}{l}\text { ASC } \\
(\%) \\
\end{array}$ \\
\hline N. Africa and W. Asia & 2.8 & 11.0 & 6.1 & 1.8 & 3 & 74 & -4 & 20 & 7 & -10 & -24 & 134 \\
\hline Sub-Saharan Africa & 19.5 & 12.9 & 6.9 & 1.9 & 1 & 20 & 25 & 27 & 26 & -6 & -13 & 119 \\
\hline S. Asia & 5.8 & 14.8 & 3.9 & 3.8 & 3 & 66 & 18 & 12 & 1 & -4 & -15 & 118 \\
\hline S.E. Asia & 4.4 & 17.1 & 7.1 & 2.4 & 1 & 35 & 27 & 22 & 14 & -7 & -13 & 120 \\
\hline N. America & 11.8 & 13.1 & 6.8 & 1.9 & 6 & 34 & 22 & 29 & 10 & -6 & -9 & 115 \\
\hline Latin America & 18.4 & 14.2 & 7.7 & 1.8 & 1 & 18 & 34 & 29 & 18 & -5 & -8 & 114 \\
\hline E. and S.E. Europe & 2.1 & 18.0 & 6.0 & 3.0 & 6 & 60 & 4 & 27 & 3 & -7 & -16 & 124 \\
\hline
\end{tabular}

Our results highlight a fundamental, yet undescribed, aspect of the 'great acceleration', that is, the observation that many aspects of the relationship between humankind and its natural world are moving ever faster ${ }^{27}$. Today, $80 \%$ of all biomass used by human society in socioeconomic processes (for example, as food, feed, fibre or fuel) originates from ecosystems with a fast turnover ${ }^{21}$ (Supplementary Fig. 2). The land-use-induced $\tau_{\mathrm{b}}$ acceleration is an integral element of land management, bound to persist due to increasing demand for many ecosystem services, in particular provisioning ones ${ }^{28}$. Hence, the influence of land management on $\tau_{\mathrm{b}}$ is likely to gain in importance.

These first order results re-emphasize the call for the systematic inclusion of land-use and management impacts on $\mathrm{C}$ state and process variables ${ }^{29}$. A significant proportion of the variability of $\tau_{\mathrm{b}}$ within each type of land cover is potentially causedbesides climatic covariates ${ }^{1,8}$ - by management effects. Inclusion of robust land management information, including its impacts on soil processes, is key for assessing the fundamental trade-offs between carbon stocks and carbon turnover related to different biomes and land-use systems, and thereby better understand land-atmosphere fluxes of carbon.

\section{Methods}

Methods, including statements of data availability and any associated accession codes and references, are available in the online version of this paper.

\section{References}

1. Bloom, A. A., Exbrayat, J.-F., Velde, I. R., van der Feng, L. \& Williams, M. The decadal state of the terrestrial carbon cycle: global retrievals of terrestrial carbon allocation, pools, and residence times. Proc. Natl Acad. Sci. USA 113, 1285-1290 (2016).

2. Körner, C. Biosphere responses to $\mathrm{CO}_{2}$ enrichment. Ecol. Appl. 10, 1590-1619 (2000).

3. Odum, E. P. Fundamentals of Ecology Vol. 3 (Saunders, 1971).

4. Saugier, B., Roy, J. \& Mooney, H. A. in Terrestrial Global Productivity (eds Roy, J., Saugier, B. \& Mooney, H. A.) 543-557 (Academic, 2001).

5. Malhi, Y. The productivity, metabolism and carbon cycle of tropical forest vegetation. J. Ecol. 100, 65-75 (2012).

6. Körner, C. et al. Carbon flux and growth in mature deciduous forest trees exposed to elevated $\mathrm{CO}_{2}$. Science 309, 1360-1362 (2005).
7. Barrett, D. J. Steady state turnover time of carbon in the Australian terrestrial biosphere. Glob. Biogeochem. Cycles 16, 55 (2002).

8. Carvalhais, N. et al. Global covariation of carbon turnover times with climate in terrestrial ecosystems. Nature 514, 213-217 (2014).

9. Keeling, H. C. \& Phillips, O. L. The global relationship between forest productivity and biomass. Glob. Ecol. Biogeogr. 16, 618-631 (2007).

10. Friend, A. D. et al. Carbon residence time dominates uncertainty in terrestrial vegetation responses to future climate and atmospheric $\mathrm{CO}_{2}$. Proc. Natl Acad. Sci. USA 111, 3280-3285 (2014).

11. Negrón-Juárez, R. I., Koven, C. D., Riley, W. J., Knox, R. G. \& Chambers, J. Q. Observed allocations of productivity and biomass, and turnover times in tropical forests are not accurately represented in CMIP5 Earth system models. Environ. Res. Lett. 10, 64017 (2015).

12. Delbart, N. et al. Mortality as a key driver of the spatial distribution of aboveground biomass in Amazonian forest: results from a dynamic vegetation model. Biogeosciences 7, 3027-3039 (2010).

13. Wang, W. et al. Diagnosing and assessing uncertainties of terrestrial ecosystem models in a multimodel ensemble experiment: 2. Carbon balance. Glob. Change Biol. 17, 1367-1378 (2011).

14. Erb, K.-H. et al. A comprehensive global 5 min resolution land-use data set for the year 2000 consistent with national census data. J. Land Use Sci. 2, 191-224 (2007).

15. Haberl, H., Erb, K.-H. \& Krausmann, F. Human appropriation of net primary production: patterns, trends, and planetary boundaries. Annu. Rev. Environ. Res. 39, 363-391 (2014).

16. Egglestone, H. S., Buendia, L., Miwa, K. \& Ngara, T. IPCC Guidelines for National Greenhouse Gas Inventories, Prepared by the National Greenhouse Gas Inventories Programme (IGES, 2006).

17. Körner, C. Paradigm shift in plant growth control. Curr. Opin. Plant Biol. 25, 107-114 (2015).

18. Galbraith, D. et al. Residence times of woody biomass in tropical forests. Plant Ecol. Diver. 6, 139-157 (2013).

19. Ahlström, A., Xia, J., Arneth, A., Luo, Y. \& Smith, B. Importance of vegetation dynamics for future terrestrial carbon cycling. Environ. Res. Lett. 10, 54019 (2015).

20. Haberl, H. et al. Quantifying and mapping the human appropriation of net primary production in Earth's terrestrial ecosystems. Proc. Natl Acad. Sci. USA 104, 12942-12947 (2007).

21. Krausmann, F. et al. Global human appropriation of net primary production doubled in the 20th century. Proc. Natl Acad. Sci. USA 110, 10324-10329 (2013).

22. Luyssaert, S. et al. Land management and land-cover change have impacts of similar magnitude on surface temperature. Nature Clim. Change $\mathbf{4}$, 389-393 (2014).

23. DeFries, R. Past and future sensitivity of primary production to human modification of the landscape. Geophys. Res. Lett. 29, 1132 (2002) 
24. Pongratz, J., Reick, C., Raddatz, T. \& Claussen, M. Effects of anthropogenic land cover change on the carbon cycle of the last millennium. Glob. Biogeochem. Cycles 23, GB4001 (2009).

25. Don, A., Schumacher, J. \& Freibauer, A. Impact of tropical land-use change on soil organic carbon stocks-a meta-analysis. Glob. Change Biol. 17, 1658-1670 (2011).

26. Global Forest Resources Assessment 2010 Main Report (FAO, 2010).

27. Steffen, W., Broadgate, W., Deutsch, L., Gaffney, O. \& Ludwig, C. The trajectory of the Anthropocene: the great acceleration. Anthrop. Rev. 2, 81-98 (2015)

28. Tilman, D., Balzer, C., Hill, J. \& Befort, B. L. Global food demand and the sustainable intensification of agriculture. Proc. Natl Acad. Sci. USA 108, 20260-20264 (2011).

29. Campioli, M. et al. Biomass production efficiency controlled by management in temperate and boreal ecosystems. Nature Geosci. 8, 843-846 (2015).

30. Thurner, M. et al. Carbon stock and density of northern boreal and temperate forests. Glob. Ecol. Biogeogr. 23, 297-310 (2014).

31. Olson, D. M. et al. Terrestrial ecoregions of the world: a new map of life on Earth a new global map of terrestrial ecoregions provides an innovative tool for conserving biodiversity. BioScience 51, 933-938 (2001).

\section{Acknowledgements}

The authors gratefully acknowledge funding from the European Research Council (ERC-2010-stg-263522 'LUISE'), the European Commission (H2020-EO-2014-640176 'BACI'), and the ProVision Programme of the Austrian Ministry of Science. We thank M. Thurner for providing the temperate-boreal woody carbon stock data set (ref. 30). This research contributes to the Global Land Project (www.globallandproject.org).

\section{Author contributions}

K.-H.E., T.F., C.P. and H.H. designed the study. K.-H.E., T.F., T.K. and C.P. performed the empirical research. All authors contributed significantly to the final analysis, interpretation or results and writing of the manuscript.

\section{Additional information}

Supplementary information is available in the online version of the paper. Reprints and permissions information is available online at www.nature.com/reprints.

Correspondence and requests for materials should be addressed to K.-H.E.

\section{Competing financial interests}

The authors declare no competing financial interests. 


\section{Methods}

Our assessment of the human-induced acceleration of $\tau_{\mathrm{b}}$ was based on a consistent integration of four spatially explicit data sets, all at a spatial resolution of $5 \mathrm{arcmin}$ : stocks of carbon (SC; standing [living] biomass, that is, excluding dead wood), and net primary production (NPP), both for the potential and actual vegetation. For all components, above- (shoot) and belowground (root) processes were considered, but not soil carbon. For input data, we did not rely on site data (for example, refs 32-35) but where possible on data compilations (for example, ref. 16), which are less sensitive to problems of site data for large-scale studies such as lack of representativeness or bias towards old-grown, intact ecosystems $\mathrm{s}^{36-38}$, and on data from official statistics (for example, ref. 26). Supplementary Tables 1 and 2 give an overview on the different approaches. Supplementary Tables 5-7 display input data, and Supplementary Tables 6 and $8-10$ show their relation to site data.

Land-use data set. A comprehensive (that is, including all land uses for all grid cells) spatially explicit land-use data set is required for assessing the specific impact of land use on $\tau_{\mathrm{b}}$. An existing data set ${ }^{14}$, which discerns four land-use types (infrastructure, cropland, forestry, grazing land) and wilderness areas in fractional cover representation at a resolution of $5 \mathrm{arcmin}$, served as starting point. This data set is consistent with national cropland and forestry statistics for the year 2000 (published around 2005) and remote sensing (RS) information. Wilderness contains unproductive areas (mapped on the basis of combinations of productivity thresholds from ref. 20 and land-cover data on, for example, permanent snow cover $^{39}$ ) and productive, often remote areas (mapped on basis of ref. 40).

In a first step, the cropland and forestry layers were adjusted to reproduce to newly published national statistics for cropland and forests for the year 2000 (based on the regular updates by ref. 26,41). In ref. 14, all land not used for infrastructure, cropland or forestry, but which is still used, is assumed to be under grazing regimes, albeit at varying intensities. This layer was split into three individual layers of grazing land. First, artificial grasslands, that is, grasslands on potentially forested areas, have been identified by intersecting forest biome maps by refs $31,42,43$ with grazing areas identified as cultivated and managed by ref. 39, but not covered by cropland ${ }^{14}$. Second, grazing land with trees (for example, other wooded land, $\mathrm{OWL}$ ); and third, grazing areas without trees, were separated using data from the MODIS global percentage tree cover map ${ }^{44}$, available at $500 \mathrm{~m}$ resolution. The latter represents grid cells with tree cover $<5 \%$, aggregated to a resolution of $5 \mathrm{arcmin}$. The final land-use data set discerns the following nine classes: Unused land, three classes: non-productive and snow; wilderness, productive, without trees; untouched forests; Used land, six classes: infrastructure area; cropland; forestry; artificial grassland; natural grassland without trees (for example, steppes); savannah, other wooded land, shrubs and grassland-tree mosaics. No vegetation, and thus no turnover, is assumed to prevail in cold and hot deserts.

NPP of the potential vegetation $\left(\mathrm{NPP}_{\mathrm{pot}}\right) \cdot \mathrm{NPP}_{\mathrm{pot}}$ data were derived by combining three different model approaches: the Miami model based on empirical relationships between NPP and climate variable ${ }^{45}$; the model result of the dynamic global vegetation model $\mathrm{LP}^{46-48}$, a well-established biogeochemical process model of global vegetation; and a vegetation-approach model. The latter was calculated by assigning typical NPP values for undisturbed vegetation ${ }^{4}$ (Supplementary Tables 3 and 4) to the global biome, using three maps ${ }^{31,42,43}$ and computing the arithmetic mean in each grid cell of the resulting maps.

NPP of the actual vegetation $\left(\mathrm{NPP}_{\text {act }}\right)$. Cropland $\mathrm{NPP}_{\text {act }}$ was taken from previous work, which extrapolated NPP from primary crop harvest, applying region- and plant-specific factors such as dry matter content and harvest indices, as well as factors for pre-harvest losses ${ }^{49,50}$. For non-cropland areas, $\mathrm{NPP}_{\text {act }}$ was assessed by calculating differences to $\mathrm{NPP}_{\text {pot }}$ due to management ${ }^{15,20,21}$. For artificial grazing lands $\mathrm{NPP}_{\text {act }}$ was assumed to be $78 \%$ of $\mathrm{NPP}_{\text {pot }}$, to take the effects of leaf area reductions, shortening of the vegetation period and nutrient withdrawals into account ${ }^{20}$. For natural grazing lands-that is, grazing lands located on natural temperate or tropical grasslands-we assume $\mathrm{NPP}_{\text {act }}$ to equal $\mathrm{NPP}_{\text {pot }}$, as in many cases livestock is not changing the overall carrying capacity (including wild herbivores) of such areas ${ }^{20}$. An exemption is human-induced degradation, which was assessed by combining spatially explicit maps on the extent and degree of degradation with factors for NPP-losses per degree ${ }^{51,52}$ (Supplementary Information). Additionally, NPP-enhancing effects of intensive grassland management, for example, due to fertilization or irrigation, were taken into account $^{20}$ (Supplementary Information). NPP act on infrastructure areas was calculated as one-third of $\mathrm{NPP}_{\text {pot }}$, assuming that two-thirds of the surface are sealed by buildings, roads, and so on, and bear no vegetation, and the one-third bears vegetation with potential productivity.

For forests, we assumed $\mathrm{NPP}_{\text {act }}$ to equal $\mathrm{NPP}_{\text {pot }}$.(see below), which is corroborated by recent empirical evidence that found similar NPP levels for managed and unmanaged stands ${ }^{34}$, as well as by regional studies of the Human Appropriation of NPP based on inventory data ${ }^{53,54}$. However, the literature is not conclusive, describing two opposite effects of management on forest NPP. On the one hand, management is argued to enhance NPP through increasing soil fertility (increased litter flow) and declining light competition ${ }^{34}$, as well as through the juvenilization effect of forest management ${ }^{55}$ that reduced the fraction of old-grown stands with lower $\mathrm{NPP}^{35,56,57}$. On the other hand, the reduction of NPP due to clear cut areas ${ }^{58,59}$ is argued to reduce NPP, reflected in inventory- or process-model-based approaches that find NPP to decline by $-29 \%$ to $-9 \%$. However, uncertainty on the magnitude of these effects is large. From these results, as well as from the reasoning that forest harvest is a form of disturbance which leads to a reduction of average residence time, we conclude that the land-use impact on NPP ranges between $\pm 10 \%$, which we use in a sensitivity analysis (see below).

This procedure to assess $\mathrm{NPP}_{\text {act }}$ has been shown to provide robust results despite the uncertainties related to statistical data, to assumptions underlying the applied estimation procedures, and to the NPP data derived from global vegetation models, because it is based on careful, cross-checked estimation procedures ${ }^{15,21}$.

Carbon stock of the potential vegetation $\left(\mathrm{SC}_{\mathrm{pot}}\right)$. Potential biomass carbon stocks (above- and belowground) were derived following a vegetation approach that was based on the delineation of homogeneous vegetation units, and the attribution of typical potential carbon stock values to these vegetation units (Supplementary Table 3). We followed the same procedure as with the $\mathrm{NPP}_{\text {pot }}$ assessment, using three global biome maps ${ }^{31,42,43}$. We used various databases for potential carbon stocks in vegetation $^{4,16,60-63}$. For boreal forests, a comparison with primary data from refs $64-$ 66 and the analysis in ref. 36 revealed overestimates in the above-mentioned sources. Thus, we derived maxima values from ref. 67 for undisturbed ecosystems for this region. Supplementary Table 5 shows potential vegetation units and the potential carbon stock values assigned, and Supplementary Tables 8-12 show results from forest site-data studies that explicitly discern natural from managed forest ${ }^{32,33}$. A comparison of these data reveals that the data we use are well in line with the site-specific studies ${ }^{36,37}$. $\mathrm{SC}_{\text {pot }}$ was then calculated as the arithmetic mean of all three maps for each grid cell.

Carbon stock of the actual vegetation $\left(\mathrm{SC}_{\text {act }}\right)$. The assessment of $\mathrm{SC}_{\text {act }}$ for forests was based on carbon stock data from a global compilation of forest inventories by the Forest Resource Assessment (FRA ${ }^{26}$. Inventory-derived C-stock estimates are considered to be reliable, in particular for forest under production ${ }^{68,69}$, they are available with global coverage (in contrast to, for example, RS-derived products) and represent the basis of many studies ${ }^{16}$. In addition, they are considered more robust than landscape-scale extrapolations based purely on site data, as they allow one to overcome the problems of representativenes ${ }^{37,70,71}$. We used mean tree height ${ }^{72}$ to downscale national carbon stock data per unit forest area to the $5 \mathrm{arcmin}$ grid. Tree height is a central parameter for the amount of carbon stored in forests, and has been shown to considerably improve the performance of allometric models that are used to quantify tree mass by non-destructive sampling ${ }^{73,74}$. The relative neglect of tree height in allometric approaches is based on the difficulties associated with measuring it ${ }^{38,74}$. Simple allometric functions (for example, ref. 75 ) follow the formula tree mass $=$ density $\times(0.5 \text { diameter })^{2} \times$ tree height, assuming, for example, near-cylindrical form of tree boles (which store most of a forest's biomass; ref. 61), suggesting that tree height has decisive influence due to tree architecture (height is much larger than diameter). While for temperate and boreal forests, based on sitedata analyses, tree height is found to be a good indicator for carbon stocks at larger scales $^{36,76}$, the interrelation is less straightforward, but still strong, for tropical forests, due to the high structural complexity, species variability, and variations

in wood density, stem diameter, and the number of trees per area, as well as due to environmental factors ${ }^{77,78}$. As we use tree-height information only for downscaling national carbon stock data to the grid, rather than to calculate carbon stocks from allometric relationships, the related problems-that is, the heterogeneity of wood density and species ${ }^{16}$-are less important sources of uncertainty in our study. Furthermore, a comparison of tree-height data ${ }^{72}$ with RS-based C-stock maps, themselves based on interpretations of lidar data by use of allometric functions derived from site data, reveals a strong linear correlation $\left(R^{2}>0.7\right.$; Supplementary Fig. 1). In the light of the considerable uncertainties between RS products, as well as with site data ${ }^{79-81}$, we accepted the uncertainty we introduce through tree-height-based downscaling for the advantage of consistency, because national forest $\mathrm{C}$-stock data are available with global coverage ${ }^{26}$. Other approaches that have been proposed for downscaling national carbon stock information, for example, following the pattern of NPP ${ }^{82}$, would result in one national $\tau_{\text {bact }}$ value for forest. Note that such downscaling techniques would affect the spatial pattern of $\tau_{\mathrm{b}}$ acceleration (for example, Fig. 1), but not significantly change the overall result at higher spatial aggregates such as world regions, biomes or land-use types.

Minimum carbon stocks for forests were set to $3 \mathrm{kgC} \mathrm{m}^{-2}$, a value below typical values for scrublands ${ }^{4}$, to avoid $\mathrm{SC}_{\text {act }}$ of forests falling below $\mathrm{SC}_{\text {act }}$ of savannahs and other wooded land $(\mathrm{OWL})$. For this land-cover type literature data is inconsistent (Supplementary Table 6). FRA ${ }^{26}$, however, provides data on growing stock (woody stems $>10 \mathrm{~cm}$ diameter, in $\mathrm{m}^{3}$ ) for some countries. For these countries, growing stock of OWL ranges between $0.4 \%$ and $21 \%$ (inner quartiles) of forest carbon stocks, with a global, stock-weighted, average of $23 \%$ (Supplementary Table 7). 
To take non-woody and belowground components into account, which are of larger importance for this vegetation type compared to forests, as well to produce a conservative estimate, we assumed OWL carbon densities to be $50 \%$ of forest biomass in each grid cell, which we modulated in a sensitivity analysis (see

below). We calculated the national carbon stock per OWL area and downscaled it to the grid using the same procedure as with forest $\mathrm{SC}_{\text {act }}$. To avoid implausible results, in each grid cell the resulting $\mathrm{SC}_{\text {act }}$ was corrected where necessary not to surpass $\mathrm{SC}_{\text {act }}$ of forests. For other vegetation, for example, natural grasslands without trees, we assumed $\mathrm{SC}_{\text {act }}$ to equal $\mathrm{SC}_{\mathrm{pot}}$. For natural grazing lands with a tree cover $<5 \%$ we assumed $\mathrm{SC}_{\text {act }}$ equal to the minimum of $\mathrm{SC}_{\text {pot }}$ and $\mathrm{SC}_{\text {act }}$ of $\mathrm{OWL}$ in each grid cell.

For cropland and artificial grasslands, $\mathrm{SC}_{\text {act }}$ was set to $\mathrm{NPP}_{\text {act }}$, assuming biomass turnover to be $1 \mathrm{yr}$ (ref. 8). $\mathrm{SC}_{\text {act }}$ on infrastructure areas was assumed to be one-third of $\mathrm{SC}_{\mathrm{pot}}$, in line with the assumption for $\mathrm{NPP}_{\text {act }}$ in this land-use class ${ }^{20}$. In the absence of information on the effect of land-use-induced degradation on $\tau_{\mathrm{b}}$, we neglected this effect, reducing $\mathrm{SC}_{\text {act }}$ on grazing land with the same factor used to derive the NPP loss due to degradation (see above). Cropland and forest degradation is reflected in the data, as their $\mathrm{SC}_{\text {act }}$ was derived from statistics.

Consistency adjustments. To provide a consistent account, in grid cells where $\mathrm{SC}_{\text {act }}$ was larger than $\mathrm{SC}_{\text {pot }}, \mathrm{SC}_{\text {pot }}$ was raised to $\mathrm{SC}_{\text {act }}$ levels. $\mathrm{SC}_{\text {act }}$ and $\mathrm{SC}_{\text {pot }}$ values were not allowed to fall below $\mathrm{NPP}_{\text {act }}$ and $\mathrm{NPP}_{\text {pot }}$ values, respectively, to avoid $\tau_{\mathrm{b}}$ falling below the minimum temporal resolution ( $1 \mathrm{yr}$ ). Turnover times were capped at $50 \mathrm{yr}$ to avoid a typical small number problem, as usual biomass turnover times for slow vegetation forms ranges between 20 and $30 \mathrm{yr}$ (refs $4,9,83,84)$. $\tau_{\mathrm{b}}$ acceleration, as the ratio between two intensive variables, was particularly prone to small number problems, and capped at a factor of 20 .

Uncertainty assessment. To evaluate the robustness of our results, we performed an analysis that used alternative, independent data sets for $\mathrm{NPP}_{\mathrm{pot}}, \mathrm{NPP}_{\text {act }}$, $\mathrm{SC}_{\mathrm{pot}}$ and $\mathrm{SC}_{\mathrm{act}}$ for constructing a sample space for $\tau_{\mathrm{b}}$ of the potential and actual vegetation.

For $\mathrm{SC}_{\text {act }}$, we compiled or calculated five alternative maps. Two maps were based on a combination of three RS products ${ }^{30,85,86}$, which cover woody biomass only ${ }^{30,79}$. We used two different land-cover maps to discern woody from non-woody vegetation (reclassifications of the GLC2000 ${ }^{39}$, available at the resolution of $1 \mathrm{~km}$, and the MODIS continuous field data set for tree cover ${ }^{44}$, available at the resolution of $500 \mathrm{~m}$ ). For areas not covered by woody vegetation according to these sources, we used NPP data from MODIS ${ }^{87}$, assuming a turnover of one year on these areas ${ }^{8}$. As the spatial extent of the RS maps overlaps considerably, we used the minimum and maximum value in each grid cell to derive two $\mathrm{SC}_{\text {act }}$ maps. A third and fourth $\mathrm{SC}_{\text {act }}$ map were constructed using the same data sources and assumptions as in the best-guess approach for all vegetation units, but assuming OWL to be at $25 \%$ and $75 \%$ of forest $\mathrm{SC}_{\text {act }}$. A published $\mathrm{SC}_{\text {act }}$ map $^{63}$ was used as fifth map in the uncertainty assessment.

For $\mathrm{SC}_{\text {pot }}$, we calculated three different maps. For the first two maps we followed the vegetation approach used for the best guess estimated (three biome maps combined with typical $\mathrm{SC}_{\text {pot }}$ values for the individual vegetation types), using $\mathrm{SC}$ values from alternative literature sources ${ }^{4,60,62}$ (Supplementary Table 5) and calculating a minimum and maximum map. We did this by using the minimum and maximum value per grid cell of the three biome maps and our best-guess map. A published carbon stock map ${ }^{88}$ was used as a third $\mathrm{SC}_{\mathrm{pot}}$ map.

For $\mathrm{NPP}_{\text {pot }}$, we calculated the grid-based minimum and maximum of the three input layers, that is, the result of the Miami Model ${ }^{45}$, the LPJ-DGVM ${ }^{20,21,46}$, and the vegetation-approach based map using data from ref. 4 (see Supplementary Table 1) resulting in two alternative $\mathrm{NPP}_{\text {pot }}$ maps.

For NPP act we used two independent maps, that is, the RS-based NPP map from MODIS ${ }^{87}$ as well as the NPP ${ }_{\text {act }}$ layer from ref. 20.

The combination of all results, including the best-guess estimates, resulted in $216 \tau_{\mathrm{b}}$ acceleration combinations. Each combination was adjusted individually to avoid inconsistencies. $\mathrm{SC}_{\text {pot }}$ was adjusted to $\mathrm{SC}_{\text {act }}$ in cases $\mathrm{SC}_{\text {act }}>\mathrm{SC}_{\text {pot }}$, and $\mathrm{SC}_{\text {act }}$ and $\mathrm{SC}_{\text {pot }}$ were adjusted in order not to fall below $\mathrm{NPP}_{\text {act }}$ and $\mathrm{NPP}_{\text {pot }}$, respectively. We calculated the ratio between maximum and minimum for all four $\tau_{\text {bacc }}$ input variables $\left(\mathrm{SC}_{\mathrm{pot}}, \mathrm{SC}_{\mathrm{act}}, \mathrm{NPP}_{\mathrm{pot}}, \mathrm{NPP}_{\mathrm{act}}\right.$ ) separately, and used the sum of the four quotients as the estimate of overall uncertainty. Supplementary Fig. 3 shows the spatial uncertainty pattern, as well the contribution of the four individual quotients (log-transformed), aggregated to a fishnet with a side length of $1.4 \times 10^{6} \mathrm{~m}$.

In a sensitivity analysis we assessed the effect of different assumptions on $\mathrm{SC}_{\text {act }}$ for OWL and of natural grasslands without trees, by assuming OWL to reach a $\mathrm{SC}_{\text {act }}$ of $25 \%$ and $75 \%$ of forest $\mathrm{SC}_{\text {act }}$. The effect of assumptions on forest $\mathrm{NPP}_{\text {act }}$ was quantified by setting this value to $90 \%$ and $110 \%$ of $\mathrm{NPP}_{\text {pot }}$ (Supplementary Tables 14 and 15).

\section{Assessment of the contribution of land-use types and components to $\boldsymbol{T}_{\mathrm{b}}$}

acceleration. $\tau_{\mathrm{b}}$ acceleration is the ratio of two variables, $\tau_{\text {bpot }}$ and $\tau_{\text {bact }}$, which themselves are ratios of two variables, $\mathrm{SC}_{\text {pot }}$ and $\mathrm{NPP}_{\text {pot }}$ and $\mathrm{SC}_{\text {act }}$ and $\mathrm{NPP}_{\text {act }}$, respectively. This hampers the simple assessment of the contribution of individual components, for example, C-stock changes or individual land-use types. Thus, we performed a decomposition analysis using the following identity for $\tau_{\mathrm{b}}$ :

$$
\tau_{\mathrm{b}}=\frac{\mathrm{NPP}_{\mathrm{i}}}{\mathrm{NPP}} \times \frac{1}{\mathrm{NPP}_{\mathrm{i}}} \times \frac{\mathrm{SC}_{\mathrm{i}}}{1}
$$

Formula (2) distinguishes the following factors: $\mathrm{NPP}_{\mathrm{i}} / \mathrm{NPP}$ is a structural factor, denoting the share of NPP of a land-use type $i$ in the total NPP. $1 / \mathrm{NPP}_{\mathrm{i}}$, expresses the influence of the NPP of land-use type i. $\mathrm{SC}_{\mathrm{i}} / 1$ expresses the influence on the SC of land-use type. We applied the additive Logarithmic Mean Divisia Index (LMDI) decomposition method $^{89}$ to actual and potential $\tau_{\mathrm{b}}$ values to assess the contribution of changes in the three factors, as well as of the five land-use types (infrastructure, cropland, forestry, artificial grassland, natural grassland and savannah) to overall $\tau_{\mathrm{b}}$ acceleration. Areas without land use were excluded from this analysis (Supplementary Table 4).

Code availability. The code is not available due to the multitude and complex computation steps performed in different software environments-that is, GIS environments (ESRI ArchGis), Matlab and Microsoft Excel.

Data availability. Results are available from http://www.uni-klu.ac.at/socec/ inhalt/1088.htm. Data and maps can be obtained at http://www.uni-klu.ac.at/socec. Underlying data, for example, data from other sources, which support the findings of this study are available from the corresponding author upon request.

\section{References}

32. Luyssaert, S. et al. $\mathrm{CO}_{2}$ balance of boreal, temperate, and tropical forests derived from a global database. Glob. Change Biol. 13, 2509-2537 (2007).

33. Bond-Lamberty, B. \& Thomson, A. A global database of soil respiration data. Biogeosciences 7, 1915-1926 (2010).

34. Noormets, A. et al. Effects of forest management on productivity and carbon sequestration: a review and hypothesis. Forest Ecol. Manag. 355, 124-140 (2015).

35. Michaletz, S. T., Cheng, D., Kerkhoff, A. J. \& Enquist, B. J. Convergence of terrestrial plant production across global climate gradients. Nature 512, $39-43$ (2014).

36. Fang, J. et al. Overestimated biomass carbon pools of the northern mid- and high latitude forests. Clim. Change 74, 355-368 (2006).

37. Brown, S. \& Lugo, A. E. Biomass of tropical forests: a new estimate based on forest volumes. Science 223, 1290-1293 (1984).

38. Brown, S. Estimating Biomass and Biomass Change of Tropical Forests: A Primer (Food \& Agriculture Org., 1997).

39. Bartholomé, E. \& Belward, A. S. GLC2000: a new approach to global land cover mapping from Earth observation data. Int. J. Remote Sens. 26, 1959-1977 (2005).

40. Sanderson, E. W. et al. The human footprint and the last of the wild. BioScience 52, 891-904 (2002).

41. Statistical Databases (FAOSTAT, accessed 13 October 2014); http://faostat.fao.org

42. FAO Global Ecological Zoning for the Global Forest Resources Assessment, 2000 (Food and Agriculture Organization of the United Nations, 2001).

43. Ramankutty, N. \& Foley, J. A. Estimating historical changes in global land cover: croplands from 1700 to 1992. Glob. Biogeochem. Cycles 13, 997-1027 (1999).

44. DiMiceli, C. M. et al. Vegetation Continuous Fields MOD44B 20011 Percent Tree Cover, Collection 5. (University of Maryland, accessed 10 October 2014); http://glcf.umd.edu/data/vcf

45. Lieth, H. Primary Productivity of the Biosphere 237-263 (Springer, 1975).

46. Bondeau, A. et al. Modelling the role of agriculture for the 20th century global terrestrial carbon balance. Glob. Change Biol. 13, 679-706 (2007).

47. Gerten, D., Schaphoff, S., Haberlandt, U., Lucht, W. \& Sitch, S. Terrestrial vegetation and water balance-hydrological evaluation of a dynamic global vegetation model. J. Hydrol. 286, 249-270 (2004).

48. Sitch, S. et al. Evaluation of the terrestrial carbon cycle, future plant geography and climate-carbon cycle feedbacks using five Dynamic Global Vegetation Models (DGVMs). Glob. Change Biol. 14, 2015-2039 (2008).

49. Ciais, P. et al. The European carbon balance. Part 2: croplands. Glob. Change Biol. 16, 1409-1428 (2010).

50. Krausmann, F., Erb, K.-H., Gingrich, S., Lauk, C. \& Haberl, H. Global patterns of socioeconomic biomass flows in the year 2000: a comprehensive assessment of supply, consumption and constraints. Ecol. Econ. 65, 471-487 (2008).

51. Oldeman, L. R., Hakkeling, R. T. A. \& Sombrock, W. G. World Map of the Status of Human-Induced Soil Degradation (ISRIC Wageningen, 1991).

52. Zika, M. \& Erb, K. H. The global loss of net primary production resulting from human-induced soil degradation in drylands. Ecol. Econ. 69, 310-318 (2009). 
53. Haberl, H. et al. Changes in ecosystem processes induced by land use: human appropriation of aboveground NPP and its influence on standing crop in Austria. Glob. Biogeochem. Cycles 15, 929-942 (2001).

54. O’Neill, D. W., Tyedmers, P. H. \& Beazley, K. F. Human appropriation of net primary production (HANPP) in Nova Scotia, Canada. Reg. Environ. Change 7, 1-14 (2006).

55. Harmon, M. E., Ferrell, W. K. \& Franklin, J. F. Effects on carbon storage of conversion of old-growth forests to young forests. Science $\mathbf{2 4 7}$, 699-702 (1990).

56. Ryan, M. G., Binkley, D. \& Fownes, J. H. Age-related decline in forest productivity. Adv. Ecol. Res. 27, 213-262 (1997).

57. Zaehle, S. et al. The importance of age-related decline in forest NPP for modeling regional carbon balances. Ecol. Appl. 16, 1555-1574 (2006).

58. Saikku, L., Mattila, T., Akujärvi, A. \& Liski, J. Human appropriation of net primary production in Finland during 1990-2010. Biomass Bioenergy 83, 559-567 (2015).

59. Larocque, G. R. Ecological Forest Management Handbook (CRC, 2016).

60. Olson, J. S., Watts, J. A. \& Allison, L. J. Carbon in Live Vegetation of Major World Ecosystems (Oak Ridge National Laboratory, 1983).

61. Cannell, M. G. R. World Forest Biomass and Primary Production Data 67 (Academic, 1982)

62. Ajtay, G. L., Ketner, P. \& Duvigneaud, P. The Global Carbon Cycle. SCOPE 13 129-182 (Wiley, 1979).

63. Ruesch, A. \& Gibbs, H. K. New IPCC Tier-1 Global Biomass Carbon Map for the Year 2000 (Oak Ridge National Laboratory, accessed 15 January 2015); http://cdiac.ornl.gov/epubs/ndp/global_carbon/carbon_documentation.html

64. Amthor, J. S. et al. Boreal forest $\mathrm{CO}_{2}$ exchange and evapotranspiration predicted by nine ecosystem process models: intermodel comparisons and relationships to field measurements. J. Geophys. Res. 106, 33623-33648 (2001).

65. Gower, S. T. et al. Carbon distribution and aboveground net primary production in aspen, jack pine, and black spruce stands in Saskatchewan and Manitoba, Canada. J. Geophys. Res. 102, 29029-29041 (1997).

66. Jarvis, P. G., Saugier, B. \& Schulze, E.-D. in Terrestrial Global Productivity (eds Roy, J., Saugier, B. \& Mooney, H. A.) 211-244 (Academic, 2001).

67. Pan, Y. et al. A large and persistent carbon sink in the World's forests. Science 333, 988-993 (2011).

68. Kauppi, P. E. New, low estimate for carbon stock in global forest vegetation based on inventory data. Silva Fenn. 37, 451-457 (2003).

69. MacDicken, K. G. Global Forest Resources Assessment 2015: What, why and how? Forest Ecol. Manag. 352, 3-8 (2015).

70. Clark, D. B. \& Kellner, J. R. Tropical forest biomass estimation and the fallacy of misplaced concreteness. J. Veg. Sci. 23, 1191-1196 (2012).

71. Houghton, R. A., Lawrence, K. T., Hackler, J. L. \& Brown, S. The spatial distribution of forest biomass in the Brazilian Amazon: a comparison of estimates. Glob. Change Biol. 7, 731-746 (2001).
72. Simard, M., Pinto, N., Fisher, J. B. \& Baccini, A. Mapping forest canopy height globally with spaceborne lidar. J. Geophys. Res. 116, G04021 (2011).

73. Nogueira, E. M., Fearnside, P. M., Nelson, B. W., Barbosa, R. I. \& Keizer, E. W. H. Estimates of forest biomass in the Brazilian Amazon: new allometric equations and adjustments to biomass from wood-volume inventories. Forest Ecol. Manag. 256, 1853-1867 (2008).

74. Feldpausch, T. R. et al. Tree height integrated into pantropical forest biomass estimates. Biogeosciences 9, 3381-3403 (2012).

75. Chave, J. et al. Improved allometric models to estimate the aboveground biomass of tropical trees. Glob. Change Biol. 20, 3177-3190 (2014).

76. Lefsky, M. A. et al. Lidar remote sensing of above-ground biomass in three biomes. Global Ecol. Biogeogr. 11, 393-399 (2002).

77. Drake, J. B. et al. Estimation of tropical forest structural characteristics using large-footprint lidar. Remote Sens. Environ. 79, 305-319 (2002).

78. Asner, G. P. High-resolution forest carbon stocks and emissions in the Amazon Proc. Natl Acad. Sci. USA 107, 16738-16742 (2010).

79. Mitchard, E. T. et al. Uncertainty in the spatial distribution of tropical forest biomass: a comparison of pan-tropical maps. Carbon Balance Manag. 8, 10 (2013).

80. Mitchard, E. T. A. et al. Markedly divergent estimates of Amazon forest carbon density from ground plots and satellites. Glob. Ecol. Biogeogr. 23, 935-946 (2014)

81. Saatchi, S. et al. Seeing the forest beyond the trees. Glob. Ecol. Biogeogr. 24, 606-610 (2015)

82. Kindermann, G. E., McCallum, I., Fritz, S. \& Obersteiner, M. A global forest growing stock, biomass and carbon map based on FAO statistics. Silva Fenn. 42, 387-396 (2008).

83. Bolin, B. in The Greenhouse Effect, Climatic Change, and Ecosystems. SCOPE 29 (eds Bolin, B., Döös, B. R., Jäger, J. \& Warrick, R. A.) 93-155 (Wiley, 1986).

84. Pan, Y., Birdsey, R. A., Phillips, O. L. \& Jackson, R. B. The structure, distribution, and biomass of the World's forests. Annu. Rev. Ecol. Evol. Syst. 44, 593-622 (2013).

85. Baccini, A. et al. Estimated carbon dioxide emissions from tropical deforestation improved by carbon-density maps. Nature Clim. Change 2, 182-185 (2012)

86. Saatchi, S. S. et al. Benchmark map of forest carbon stocks in tropical regions across three continents. Proc. Natl Acad. Sci. USA 108, 9899-9904 (2011).

87. Zhao, M., Heinsch, F. A., Nemani, R. R. \& Running, S. W. Improvements of the MODIS terrestrial gross and net primary production global data set. Remote Sens. Environ. 95, 164-176 (2005).

88. West, P. C. et al. Trading carbon for food: global comparison of carbon stocks versus crop yields on agricultural land. Proc. Natl Acad. Sci. USA 107, 19645-19648 (2010).

89. Ang, B. W. The LMDI approach to decomposition analysis: a practical guide. Energy Policy 33, 867-871 (2005). 